\title{
TO WHAT EXTENT THE APPLICATION OF MALCOLM BALDRIGE OF THE COMPREHENSIVE QUALITY STANDARDS IN THE AFTER- SALES SERVICES/ APPLIED RESEARCH IN ONE OF THE PRIVATE SECTOR COMPANIES
}

Alaa N. Al-Heali ${ }^{1}$, Wisal A. Husain ${ }^{2}$

${ }^{1}$ Lecturer, Department of Research and Studies, Market Research and Consumer Protection Center, University of Baghdad, Baghdad, Iraq. alaanabeelal@mracpc.uobaghdad.edu.iq

${ }^{2}$ Lecturer PhD., Department of Research and Studies, Market Research and Consumer Protection Center, University of Baghdad. Baghdad, Iraq.wesalab@mracpc.uobaghdad.edu.iq

Received 15/ 4/ 2021, Accepted 29/ 6/ 2021, Published 31/ 12/ 2021

This work is licensed under a CCBY 4.0 https://creativecommons.org/licenses/by/4.0

\begin{abstract}
The aim of the research is to identify to what extent to which Malcolm Baldrige standards of total quality are applied in the after-sales services of a private sector company for electrical appliances, from the point of view of administrative leaders, in it. To achieve this aim a questionnaire has been used to measure the degree of application of Malcolm's seven criteria for total quality, namely: (leadership, strategic planning, focus on the customer, measurement and analysis and knowledge management, focus in human resource and operation management and results of the company's management), the research found that the company achieved a good level of the standard from the degree of the standard in the award. The research recommends a comprehensive quality management system through the application of Malcolm's criteria for quality in the field of after sales services and selection of administrative leaderships that have experience in applying quality standards.


Iraqi Journal of Market Research and Consumer Protection

مدى تطبيق معايير مالكولم بالدريج للجودة الثاملة في مجال خدمات ما بعد البيع/ بحث تطبيقي في احدى شركات القطاع

الاء نبيل عبل الرزاق 1، وصال عبل الله حسبن 2

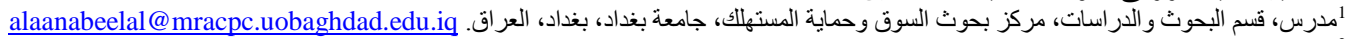

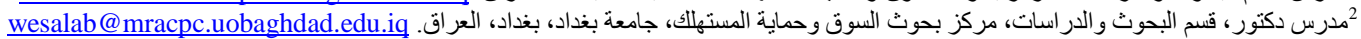

Received 15/ 4/ 2021, Accepted 29/ 6/ 2021, Published 31/12/ 2021

This work is licensed under a CCBY $4.0 \mathrm{https://creativecommons.org/licenses/by/4.0}$

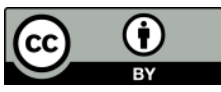

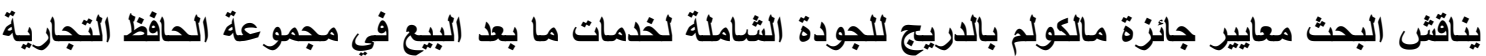

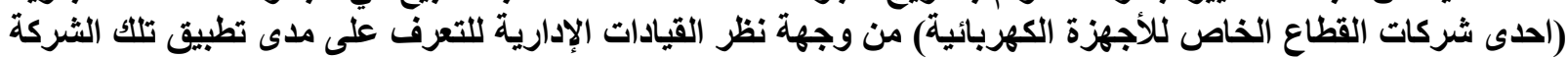

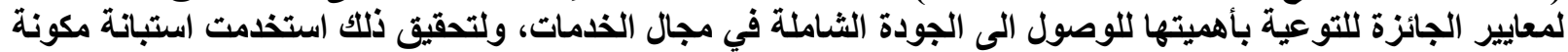

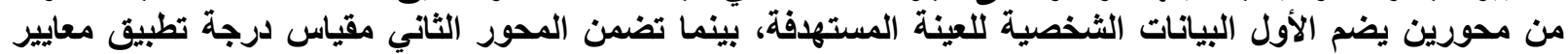

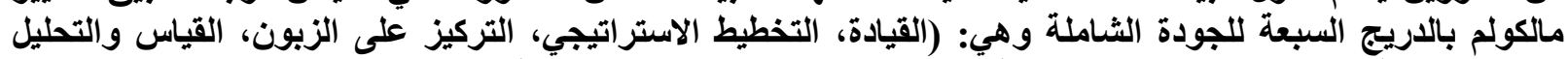

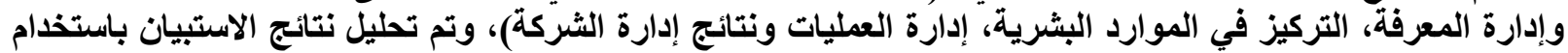

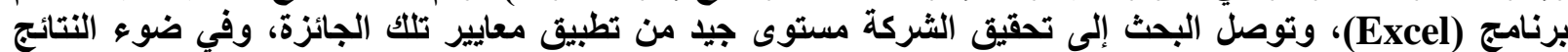

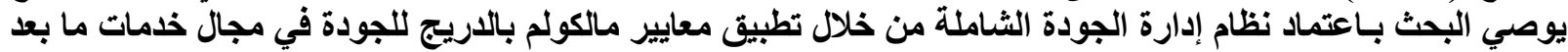

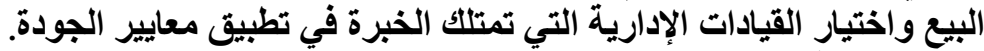

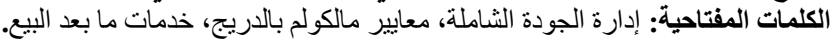

\section{INTRODUCTION}

Some organizations believe that their role ends when selling products or services and receiving their money, but after-sales services are essential part of the sales strategy of any company, regardless of its size. Consumers may need other services after the product is delivered. it may be the needs for assistance in installation, training on use or maintenance, or the consumer may need to return the product due to a defect in it. After-sales service can give the company respectable reputation, which in turn increases their markets, in addition to preserving consumers (Al-Hamdany \& Abd 2018). Modern companies tend to develop their services to serve a greater number of beneficiaries and to provide the maximum services that can be provided in a way that achieves the highest possible benefit. This constitutes is an effective factor to promote company's work and its position towards discrimination in the provision of services in order to achieve the comprehensive quality (Abdul Razzaq 2011).

\section{Research problem}

The research problem is summed up by a question: What is the extent of Malcolm Baldrige application of overall quality standards in after-sales services at a private sector company?

\section{Research aims}

A. To what extent the seven criteria for the Malcolm Baldrige scale of total quality are applied in the field of after-sales services at the company researched as one of the private sector companies.

B. Identify the most important obstacles that hinder the application of Malcolm Baldrige standards for total quality in after-sales services.

\section{Research importance}

The importance of the research lies in the following:

Helping the private sector to achieve the comprehensive quality management in after-sales services. 
Research assumption

The degree of application of Malcolm Baldrige standards for total quality in the company's after-sales services in studied company is satisfy.

\section{Research limits}

This research was applied to one of the private sector companies for electrical appliances as spatial limits, while the temporal limits for the study were for the period from $6 / 6 / 2020$ to $31 / 12 / 2020$.

\section{Research methods and tools used}

The descriptive and analytical approach was used in order to understand the aspects of the topic understand its components and analyze its dimensions. In the analytical aspect, the questionnaire form was adopted after being judged by the arbitrators, which was prepared to measure the extent of application of Malcolm Baldrige standards for overall quality in aftersales services at one of the private sector company for electrical appliances, where they were distributed electronically to the leaders management in the company to know their opinions on the subject.

\section{The theoretical framework \\ The concept of total quality management}

Quality is the management philosophy of the company for all its activities with the aim of meeting the needs and desires of customers to obtain good goods and services at reasonable prices through the optimal utilization of human resources and achieving development in its activities (Hussein \& Lfteha 2019). Total quality management (TQM) makes continuous improvement, employee participation and customer satisfaction a fundamental principle and goal, considering that the needs of customers and the goals of the company are inseparable from each other, as it is a philosophy that can be applied to industry and commerce (Hussein \& Abboud 2013). Total quality management is defined according the British standards institute as a management philosophy that includes all the company's activities through which the customers' needs and expectations are fulfilled, and the company's objectives are achieved in the most efficient and cost-effective way through optimal use of the energies of all workers motivated by continuous development (Al- Saffar \& Obeidat 2020).

\section{The Malcolm Baldrige concept of total quality standards}

The Malcolm Baldrige quality award was established by the US congress in the name of Malcolm Baldrige, the former US secretary of commerce who was a major advocate for quality in order to reward industrial companies, service companies and small companies, urging them to improve their quality management programs and develop standards and guidelines that adhere to. To improve the quality of its products and services and to enhance its strategies, it was established based on the general law in 1987 during the era of the US president (Ronald Reagan), which aims at the participation of the private sector in achieving the well-being of the American citizen. Excellence in performance, it includes the standards of excellence that he derived from the Japanese Deming model, where it was developed with the aim of strengthening the concepts of general excellence for the institutions as a whole as well as the distinction of its sub-components and various departments, leading to enhancing the competitiveness of institutions among similar institutions, thus becoming an example of excellence at the level of institutions and business companies (Baldrige National Quality Program 2014).

According to the Baldrige model, the total quality is a comprehensive change for all the components of the company with the aim of satisfying the customer by continuously providing 
high quality in goods and services and providing benefit to the surrounding environment and keeping away from what harms it.

\section{Malcolm Baldrige standards for total quality}

The Malcolm Baldrige national quality award is used to measure the quality of corporate goods and services, which is called the MBNQA national quality award. The American institute for encouraging different companies to apply the concept of total quality, Malcolm Baldrige standards consist of seven main criteria for comparison, each of which is subdivided from another number of sub-elements, totaling (32) elements distributed on a scale of (1000) points that contribute to determining the level of interest and application of companies For the concept of total quality, applying the criteria of the Malcolm Baldrige Award allows companies to do the following (Kouachi 2013):

1. Upgrading the company's ability to develop its internal services and operations.

2. Commitment to high quality, fulfilling customers' desires and increasing their confidence in the company.

3. Obtaining the society's appreciation.

4. Take advantage of expert review of the company's performance level and identify strengths and weaknesses.

5. Promoting goods and services for companies that have received the Malcolm Baldrige Award.

The Malcolm Grade scale consists of seven criteria, namely (Aqaili 2001):

1. Leadership: It forms the core of the integrated system that seeks to achieve quality as it is the primary responsible for satisfying consumers. The degree has given special importance to middle and direct management, and it has also given importance to providing adequate conviction to the higher management of the feasibility of TQM, where enthusiasm for it must be present, as well as the importance of providing a degree High sense of moral and social responsibility towards the environment and society.

2. Strategic planning: Baldrige indicated that strategic planning for quality is an integrated process and indicated the necessity of making quality achievement plans coherent and achieving the planning objectives includes the following main aspects:

a. Setting long-term strategic goals that focus on customer satisfaction.

b. Establishing a new organizational culture instead of the current established.

c. Introducing radical changes to organizational performance aimed at achieving customer satisfaction.

3. Focus on the customer: Total quality management is directed towards customer satisfaction, as the customer knows that he is that person who uses the good or service (Alfkaiki \& Al- shohani 2016), by increasing the rates of customer satisfaction with the services provided to them, which in turn reduces customers' complaints about the company's services and increases its profits and market share (Chatheer et al., 2012).

4. Measurement, analysis and knowledge management: It includes collecting, analyzing and providing information in a timely manner to those who need it in a way that contributes to achieving comprehensive quality, and updating information continuously.

5. Concentration on human resources: It includes all aspects related to the quality of operation and investment of human resources, namely: Adopting the work teams approach to achieve cooperation and joint efforts. Participation and inclusion of workers in comprehensive quality planning. Follow the policy of humanitarian motivation because of its effect on raising the morale of workers. Teaching and training human resources in a way that contributes to the implementation of comprehensive quality management well. Pay 
attention to the health and safety of workers. Adopting a specific policy to measure and evaluate the performance of employees to determine the quality and development of their performance.

6. Operations management: It includes the following aspects: Quality process management: commodity design, manufacturing, materials management, quality control and evaluation. Emphasizing the necessity of preventing errors in operations by adopting effective quality control during the implementation of operations and the internal quality chain. Provide a high degree of flexibility and speed of work. Emphasis on continuous improvement of the quality of operations. Use records and documents related to quality for monitoring and evaluation purposes. Emphasis on testing the new supplier who provides supplies with a high degree of quality.

7. The results of the organization's management: It includes examining the company's performance on issues affecting its business results, including customer satisfaction, achieving goals, financial and market performance, the performance of suppliers and partners, human resources and operational performance. And also to compare the quality of the company's goods and services with those of competitors (Krajewski et al., 2010).

\section{The concept and importance of after sales services}

After-sales services are known as the set of services provided after sales by the producer or distributor, and these services are represented in the delivery of the goods, installation, maintenance and repair, help at home, periodic review or advice, they are all that corresponds outside the price limits to link the customer with a specific commodity that is distinct from a competitor's commodity of the same nature by providing the customer with a number of facilities that give him more satisfaction when using this good or service (Al-Dewa 2001). They are additional supportive services provided after the purchase process to the customer to want him to buy, increase his satisfaction and build a long good relationship with him, and that the quality of after-sales services is one of the main areas in which companies can distinguish themselves by providing high-quality services. And continuously and in a manner that surpasses the competitors' ability (Hammoud 2007).

The importance of after-sales services is due to the fact that the validity or efficiency of the devices sold and the seriousness of the accidents that may cause them only appear by using them during a certain period, which convinced the sellers that the sale has become a complex and complex agreement accompanied by many processes that start from the moment of its conclusion and are distributed during the period of use of the product and from this operations repair and maintenance service for the sold product. These services are the basis for the added value that the organization creates in technology-strengthened markets. And that after-sales services achieve several goals for the consumer, including achieving the purpose of the purchase, facilitating the use of the sold product and making good use of it, in addition to ensuring the physical and physical safety of the consumer. As for the goals achieved by the seller, they are improving the commercial reputation of the product and attracting more customers, improving the commodity manufacturing process by using information during maintenance operations, gaining a good reputation for the company by providing warranty service for the commodity according to the level of customers' aspirations, increasing the confidence of customers dealing with the company. Because trust is the basis of repeated acceptance of the company's products (Jahida \& Abdel-Wahab 2016). The after-sales services are classified into several types, including; Warranty, maintenance and repair, provision of spare parts, handling customers 'complaints (Rashid \& Gamal 2020). 


\section{The practical framework}

First: Description of the research community this topic describes the research community that has been applied to through:

\section{Description of the research sample}

The research has been applied to one of the private sector companies for electrical appliances. The questionnaire was distributed electronically to the senior leaders of the company and the number of the sample members reached (30) individuals from the higher management. The largest percentage was males, which accounted for approximately (83.3\%), and the percentage of females was the least, which constituted (16.7\%). It is noticed that the age group (less than 35 years) represents the largest part of the sample members with a percentage of $(63.4 \%)$. No results were recorded, while it is noticed that the bachelor's category occupied the largest percentage of the sample members with a percentage of $(50 \%)$. As for the diploma category, the lowest percentage of the sample members occupied (3.3\%). As it reached (53.4\%), while the number of years of experience (11-15) constituted the lowest percentage of the sample members, reaching (3.3\%). (Table 1) shows that.

Table (1): Samples distribution according to personal information.

\begin{tabular}{|c|c|c|c|c|c|c|c|c|c|c|c|}
\hline \multicolumn{12}{|c|}{ Gender } \\
\hline \multicolumn{6}{|c|}{ Male } & \multicolumn{6}{|c|}{ Female } \\
\hline \multicolumn{3}{|c|}{$(\%)$} & \multicolumn{3}{|c|}{ Freq } & \multicolumn{3}{|c|}{$(\%)$} & \multicolumn{3}{|c|}{ Freq. } \\
\hline \multicolumn{3}{|c|}{83.3} & \multicolumn{3}{|c|}{25} & \multicolumn{3}{|c|}{16.7} & \multicolumn{3}{|c|}{5} \\
\hline \multicolumn{12}{|c|}{ Age } \\
\hline \multicolumn{2}{|c|}{ Less than 35} & \multicolumn{2}{|c|}{$36-40$} & \multicolumn{2}{|c|}{$41-45$} & \multicolumn{2}{|c|}{$46-50$} & \multicolumn{2}{|c|}{$51-55$} & \multicolumn{2}{|c|}{ More than 56} \\
\hline$(\%)$ & Freq & $(\%)$ & Freq & $(\%)$ & Freq & $(\%)$ & Freq. & $(\%)$ & Freq & $(\%)$ & Freq. \\
\hline 63.4 & 19 & 6.7 & 2 & - & - & 13.3 & 4 & 13.3 & 4 & 3.3 & 1 \\
\hline \multicolumn{12}{|c|}{ Education } \\
\hline \multicolumn{2}{|c|}{ M.Sc./Ph.D. } & \multicolumn{3}{|c|}{ B.Sc. } & \multicolumn{2}{|c|}{ Higher diploma } & \multicolumn{2}{|c|}{ Diploma } & \multicolumn{3}{|c|}{ Secondary school } \\
\hline$(\%)$ & Freq & & & Freq. & $(\%)$ & Freq & $(\%)$ & Freq. & $(9$ & & Freq \\
\hline 6.7 & 2 & & & 15 & 23.3 & 7 & 3.3 & 1 & 16 & & 5 \\
\hline \multicolumn{12}{|c|}{ Years of experience in the company } \\
\hline \multicolumn{3}{|c|}{ Less than 5 years } & \multicolumn{3}{|c|}{$6-10$ years } & \multicolumn{2}{|c|}{ 11-15 years } & \multicolumn{4}{|c|}{ More than 16 years } \\
\hline$(\%)$ & Frec & & $(\%)$ & Fre & & $(\%)$ & Free & & $(\%)$ & & Freq. \\
\hline 53.4 & 15 & & 30 & 9 & & 3.3 & 1 & & 13.3 & & 4 \\
\hline
\end{tabular}

As for the percentage of those who participated in the training courses, it was (86.7\%), which is the largest percentage compared to those who did not participate in the training courses, as their percentage reached $(13.3 \%)$. (Table 2$)$.

Table (2): Distribution of the sample according to participation in the training courses.

\begin{tabular}{|c|c|c|c|}
\hline \multicolumn{4}{|c|}{ Participating in training course } \\
\hline$(\%)$ & Freq & $(\%)$ & Freq. \\
\hline 86.7 & 26 & 13.3 & 4 \\
\hline
\end{tabular}

1. Leadership criterion: We find that $(80 \%)$ of the sample members agree with the company's possession of measures to determine the effects of after-sales services on society, and (20\%) of 
them agree strongly and that $(73.3 \%)$ of the sample members agree with the company's management The principles of total quality are applied in the field of after-sales services and also laws and instructions are applied to enhance its legal behavior when providing these services and $(16.7 \%),(13.3 \%)$ of them respectively agree strongly, while we find that $(6.7 \%)$ and $(3.4 \%)$ only do not They agree with it, and also we find that $(63.3 \%)$ of the sample members agree with that the company adopts transparency in its operations and policies when providing its services, and that $(26.7 \%)$ strongly agree, and among the most prominent variables that contributed to enriching the study variables are (X1, X2, X5, x6), and this indicates that the research sample company has measures to determine the effects of after-sales services on society and applies comprehensive quality principles, laws and instructions when providing after-sales services, and also depends on transparency in its operations and policies when providing these services, and these answers have come. With a mean of (4.03) and a standard deviation of (0.755). It is in great agreement with all variants of the driving standard. (Table 3).

Table (3): Frequency distributions, percentages, and standard deviation of the leadership criterion.

\begin{tabular}{|c|c|c|c|c|c|c|c|c|c|c|c|c|c|c|}
\hline \multirow{2}{*}{$\begin{array}{l}\text { leadership } \\
\text { criterion }\end{array}$} & \multicolumn{2}{|c|}{$\begin{array}{c}\text { Strongly } \\
\text { Agree }\end{array}$} & \multicolumn{2}{|c|}{ Agree } & \multicolumn{2}{|c|}{ Neutral } & \multicolumn{2}{|c|}{ Disagree } & \multicolumn{2}{|c|}{$\begin{array}{l}\text { Strongly } \\
\text { Disagree }\end{array}$} & \multirow{2}{*}{ Mean } & \multirow{2}{*}{ St.D } & \multirow{2}{*}{$\begin{array}{c}\text { Percentages } \\
\text { of agreement } \\
\text { with } \\
\text { Question } \\
\end{array}$} & \multirow{2}{*}{$\begin{array}{l}\text { Sample } \\
\text { direction }\end{array}$} \\
\hline & Freq & $(\%)$ & Freq & $(\%)$ & Freq & $(\%)$ & Freq & $(\%)$ & Freq & $(\%)$ & & & & \\
\hline $\mathrm{X} 1$ & 5 & 16.7 & 22 & 73.3 & 1 & 3.3 & 2 & 6.7 & 0 & 0 & 4 & 0.695 & 80 & Agree \\
\hline $\mathrm{X} 2$ & 4 & 13.3 & 22 & 73.3 & 3 & 10 & 1 & 3.4 & 0 & 0 & 3.97 & 0.615 & 79.3 & Agree \\
\hline $\mathrm{X} 3$ & 11 & 36.6 & 9 & 30 & 3 & 10 & 5 & 16.7 & 2 & 6.7 & 3.73 & 1.311 & 74.7 & Agree \\
\hline $\mathrm{X} 4$ & 6 & 20 & 18 & 60 & 6 & 20 & 0 & 0 & 0 & 0 & 4 & 0.643 & 80 & Agree \\
\hline $\mathrm{X} 5$ & 8 & 26.7 & 19 & 63.3 & 3 & 10 & 0 & 0 & 0 & 0 & 4.17 & 0.592 & 83.3 & Agree \\
\hline X6 & 6 & 20 & 24 & 80 & 0 & 0 & 0 & 0 & 0 & 0 & 4.2 & 0.407 & 84 & $\begin{array}{c}\text { Strongly } \\
\text { Agree }\end{array}$ \\
\hline $\mathrm{X} 7$ & 12 & 40 & 14 & 46.7 & 4 & 13.3 & 0 & 0 & 0 & 0 & 4.27 & 0.691 & 85.3 & $\begin{array}{c}\text { Strongly } \\
\text { Agree }\end{array}$ \\
\hline $\mathrm{X} 8$ & 9 & 30 & 17 & 56.7 & 4 & 13.3 & 0 & 0 & 0 & 0 & 4.17 & 0.648 & 83.3 & Agree \\
\hline X9 & 9 & 30 & 12 & 40 & 4 & 13.3 & 3 & 10 & 2 & 6.7 & 3.77 & 1.194 & 75.3 & Agree \\
\hline Average & V.V & & IV. $\varepsilon$ & & r.1 & & $1 . r$ & & $\because \varepsilon$ & & $\varepsilon . r$ & $\because \vee 00$ & A. .7 & \\
\hline
\end{tabular}

2. Strategic planning criterion: We find that $(53.3 \%)$ of the sample members agree that the company allocates the necessary financial resources to implement the work plan for providing after-sales services and keep abreast of the major developments in technology and the telecommunications market when providing these services and (20\%), (43.3\%) of them respectively strongly agree that $(46.7 \%)$ of the respondents agree that the company is adjusting its strategic plans based on the results of performance measures, and (40\%) strongly agree, while we find that only $(6.7 \%)$ do not agree with it. (43.3\%) of the sample members agree with the company setting its strategic goals based on what the customer needs in terms of after-sales services and that the company's strategy includes goals to improve the quality of after-sales services, and that $(40 \%)$ and $(30 \%)$ of them respectively They strongly agree, and among the most prominent variables that contributed to enriching the study variables are $(\mathrm{X} 1, \mathrm{X} 3, \mathrm{X} 4, \mathrm{X} 5$, $\mathrm{X} 7$ ), and this indicates that the research sample company allocates the necessary financial resources to implement the work plan and keeps pace with developments in technology and the communications market when providing services beyond Selling, in addition to the company modifying its strategic plans based on the results of the company Ayes performance, as it sets its strategic goals based on what the customer needs from these services that it is trying to improve. These answers came with a mean (3.88) and a standard deviation of (0.892). The 
sample trends came in agreement and strongly agreement with all the variables of the strategic planning standard, (Table 4).

Table (4): frequency distributions, percentages, and standard deviation of the strategic planning criterion.

\begin{tabular}{|c|c|c|c|c|c|c|c|c|c|c|c|c|c|c|}
\hline \multirow{2}{*}{$\begin{array}{l}\text { strategic } \\
\text { planning } \\
\text { criterion }\end{array}$} & \multicolumn{2}{|c|}{$\begin{array}{c}\text { Strongly } \\
\text { Agree }\end{array}$} & \multicolumn{2}{|c|}{ Agree } & \multicolumn{2}{|c|}{ Neutral } & \multicolumn{2}{|c|}{ Disagree } & \multicolumn{2}{|c|}{$\begin{array}{l}\text { Strongly } \\
\text { Disagree }\end{array}$} & \multirow[t]{2}{*}{ Mean } & \multirow[t]{2}{*}{ St.D } & \multirow{2}{*}{$\begin{array}{l}\text { Percentages of } \\
\text { agreement } \\
\text { with Question }\end{array}$} & \multirow{2}{*}{$\begin{array}{l}\text { Sample } \\
\text { direction }\end{array}$} \\
\hline & Freq & $(\%)$ & Freq & $(\%)$ & Freq & $(\%)$ & Freq & $(\%)$ & Freq & $(\%)$ & & & & \\
\hline $\mathrm{X} 1$ & 12 & 40 & 13 & 43.3 & 5 & 16.7 & 0 & 0 & 0 & 0 & 4.23 & 0.728 & 84.7 & $\begin{array}{c}\begin{array}{c}\text { Strongly } \\
\text { agree }\end{array} \\
\end{array}$ \\
\hline $\mathrm{X} 2$ & 6 & 20 & 10 & 33.3 & 7 & 23.3 & 5 & 16.7 & 2 & 6.7 & 3.43 & 1.194 & 68.7 & Agree \\
\hline $\mathrm{X} 3$ & 6 & 20 & 16 & 53.3 & 8 & 26.7 & 0 & 0 & 0 & 0 & 3.93 & 0.691 & 78.7 & Agree \\
\hline $\mathrm{X} 4$ & 7 & 23.3 & 14 & 46.7 & 7 & 23.3 & 0 & 0 & 2 & 6.7 & 3.8 & 1.031 & 76 & Agree \\
\hline $\mathrm{X} 5$ & 9 & 30 & 13 & 43.3 & 8 & 26.7 & 0 & 0 & 0 & 0 & 4.03 & 0.765 & 80.7 & Agree \\
\hline X6 & 8 & 26.7 & 12 & 40 & 7 & 23.3 & 3 & 10 & 0 & 0 & 3.83 & 0.95 & 76.7 & Agree \\
\hline $\mathrm{X} 7$ & 13 & 43.3 & 16 & 53.3 & 1 & 3.4 & 0 & 0 & 0 & 0 & 4.4 & 0.563 & 88 & $\begin{array}{c}\text { Strongly } \\
\text { agree }\end{array}$ \\
\hline $\mathrm{X} 8$ & 5 & 16.7 & 11 & 36.7 & 7 & 23.3 & 4 & 13.3 & 3 & 10 & 3.37 & 1.217 & 67.3 & Neutral \\
\hline Average & A. ro & & $1 T .1 T$ & & $0 . r_{0}$ & & 1.0 & & $\cdot \wedge \wedge$ & & 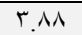 & . А१Y & $V Y . T$ & \\
\hline
\end{tabular}

3. Criterion for focusing on the customer: We find that $(63.3 \%)$ of the sample members strongly agree with the company's interest in customers' complaints and try to address them, and $(36.7 \%)$ agree with it, and that $(56.6 \%)$ of the sample members agree with the company's use of specific measures to measure satisfaction rates The customer is about after-sales services and its endeavor to know the customers' needs and desires and (16.7\%), (33.3\%) of them respectively agree strongly, and among the most prominent variables that contributed to enriching the study variables are (X1, X3, X9), and this indicates that The company research sample cares about customers' complaints and tries to address them. The company uses specific measures to measure customer satisfaction rates for after-sales services, as it seeks to know their needs and desires. These answers came with an arithmetic mean (4.1) and a standard deviation of (0.743). The sample trends came in agreement and strongly agreed with all the variables of the customer focus criterion, (Table 5).

Table (5): The frequency distributions, percentages, and standard deviation of the customer focus criterion.

\begin{tabular}{|c|c|c|c|c|c|c|c|c|c|c|c|c|c|c|}
\hline & \multicolumn{2}{|c|}{$\begin{array}{l}\text { Strongly } \\
\text { Agree }\end{array}$} & \multicolumn{2}{|c|}{ Agree } & \multicolumn{2}{|c|}{ Neutral } & \multicolumn{2}{|c|}{ Disagree } & \multicolumn{2}{|c|}{$\begin{array}{l}\text { Strongly } \\
\text { Disagree }\end{array}$} & \multirow[b]{2}{*}{ Mean } & \multirow[b]{2}{*}{ St.D } & \multirow{2}{*}{$\begin{array}{l}\text { Percentages } \\
\text { of } \\
\text { agreement } \\
\text { with } \\
\text { Question } \\
\end{array}$} & \multirow{2}{*}{$\begin{array}{c}\text { Sample } \\
\text { direction }\end{array}$} \\
\hline $\begin{array}{l}\text { customer } \\
\text { focus } \\
\text { criterion }\end{array}$ & Freq & $(\%)$ & Freq & $(\%)$ & Freq & $(\%)$ & Freq & $(\%)$ & Freq & $(\%)$ & & & & \\
\hline $\mathrm{X} 1$ & 5 & 16.7 & 17 & 56.6 & 8 & 26.7 & 0 & 0 & 0 & 0 & 3.9 & 0.662 & 78 & Agree \\
\hline $\mathrm{X} 2$ & 15 & 50 & 15 & 50 & 0 & 0 & 0 & 0 & 0 & 0 & 4.5 & 0.509 & 90 & Strongly agree \\
\hline $\mathrm{X} 3$ & 19 & 63.3 & 11 & 36.7 & 0 & 0 & 0 & 0 & 0 & 0 & 4.6 & 0.49 & 92.7 & Strongly agree \\
\hline $\mathrm{X} 4$ & 15 & 50 & 12 & 40 & 3 & 10 & 0 & 0 & 0 & 0 & 4.4 & 0.675 & 88 & Strongly agree \\
\hline $\mathrm{X} 5$ & 11 & 36.7 & 13 & 43.3 & 1 & 3.3 & 5 & 16.7 & 0 & 0 & 4 & 1.05 & 80 & Agree \\
\hline X6 & 7 & 23.3 & 14 & 46.7 & 9 & 30 & 0 & 0 & 0 & 0 & 3.9 & 0.74 & 78.7 & Agree \\
\hline $\mathrm{X} 7$ & 7 & 23.3 & 13 & 43.4 & 7 & 23.3 & 3 & 10 & 0 & 0 & 3.8 & 0.925 & 76 & Agree \\
\hline $\mathrm{X} 8$ & 6 & 20 & 15 & 50 & 7 & 23.3 & 0 & 0 & 2 & 6.7 & 3.7 & 1.006 & 75.3 & Agree \\
\hline $\mathrm{X} 9$ & 10 & 33.3 & 17 & $56 .{ }^{7}$ & 3 & 10 & 0 & 0 & 0 & 0 & 4.2 & 0.626 & 84.7 & Strongly agree \\
\hline Average & $1 . .7$ & & $1 \leqslant 1$ & & $\varepsilon . \zeta$ & & .99 & & $\cdot Y$ & & £. & $. V \leqslant r$ & Ar. 7 & \\
\hline
\end{tabular}


4. Standard for measurement, analysis and knowledge management: We find that (76.7\%) of the sample individuals agree with the company having a database about clients and competitors, and $(23.3 \%)$ of them agree strongly, and that $(70 \%)$ of the sample members agree that the company has protective measures. Suitable to ensure the reliability and safety of the technology used and it works to make the information available to all customers and that $(13.3 \%)$ and $(20 \%)$ of them respectively strongly agree, and among the most prominent variables that contributed to enriching the study variables are (X5, X7, X9), and this indicates However, the research sample company has a database about customers and competitors and appropriate protection means to ensure the reliability and safety of the technology used and make the information available to all customers, (Table 6) for frequency distributions, percentages, arithmetic mean and standard deviation of the standard of measurement, analysis and knowledge management.

Table (6): The frequency distributions, percentages, and standard deviation of the measurement, analysis and knowledge management criterion.

\begin{tabular}{|c|c|c|c|c|c|c|c|c|c|c|c|c|c|c|}
\hline \multirow[b]{2}{*}{$\begin{array}{l}\text { measurement, } \\
\text { analysis and } \\
\text { knowledge } \\
\text { management } \\
\text { criterion }\end{array}$} & \multicolumn{2}{|c|}{$\begin{array}{l}\text { Strongly } \\
\text { Agree }\end{array}$} & \multicolumn{2}{|c|}{ Agree } & \multicolumn{2}{|c|}{ Neutral } & \multicolumn{2}{|c|}{ Disagree } & \multicolumn{2}{|c|}{$\begin{array}{l}\text { Strongly } \\
\text { Disagree }\end{array}$} & \multirow[b]{2}{*}{ Mean } & \multirow[b]{2}{*}{ St.D } & \multirow{2}{*}{$\begin{array}{l}\text { Percentages } \\
\text { of } \\
\text { agreement } \\
\text { with } \\
\text { Question }\end{array}$} & \multirow[b]{2}{*}{$\begin{array}{l}\text { Sample } \\
\text { direction }\end{array}$} \\
\hline & Freq & $(\%)$ & Freq & $(\%)$ & Freq & $(\%)$ & Freq & $(\%)$ & Freq & (\%) & & & & \\
\hline 1 & 2 & 6.7 & 13 & 43.3 & 15 & 50 & 0 & 0 & 0 & 0 & 3.57 & 0.626 & 71.3 & Agree \\
\hline 2 & 4 & 13.3 & 15 & 50 & 6 & 20 & 5 & 16.7 & 0 & 0 & 3.6 & 0.932 & 72 & Agree \\
\hline 3 & 2 & 6.7 & 18 & 60 & 9 & 30 & 1 & 3.3 & 0 & 0 & 3.7 & 0.651 & 74 & Agree \\
\hline 4 & 6 & 20 & 17 & 56.7 & 7 & 23.3 & 0 & 0 & 0 & 0 & 3.97 & 0.669 & 79.3 & Agree \\
\hline 5 & 4 & 13.3 & 21 & 70 & 5 & 16.7 & 0 & 0 & 0 & 0 & 3.97 & 0.556 & 79.3 & Agree \\
\hline 6 & 3 & 10 & 13 & 43.3 & 12 & 40 & 2 & 6.7 & 0 & 0 & 3.57 & 0.774 & 71.3 & Agree \\
\hline 7 & 7 & 23.3 & 23 & 76.7 & 0 & 0 & 0 & 0 & 0 & 0 & 4.23 & 0.43 & 84.7 & $\begin{array}{c}\text { Strongly } \\
\text { Agree }\end{array}$ \\
\hline 8 & 3 & 10 & 19 & 63.3 & 8 & 26.7 & 0 & 0 & 0 & 0 & 3.83 & 0.592 & 76.7 & Agree \\
\hline 9 & 6 & 20 & 21 & 70 & 3 & 10 & 0 & 0 & 0 & 0 & 4.1 & 0.548 & 82 & Agree \\
\hline Average & 4.1 & & 17.7 & & 7.2 & & 0.8 & & · & & r.Ar & $. T \leq Y$ & V५. V & \\
\hline
\end{tabular}

5. Criterion for concentration in human resources: We find that (70\%) of the sample members agree with the company's selection and appointment of workers on scientific and laid-down foundations that serve the interest of the company, and $(6.65 \%)$ of them agree strongly, while $(6.65 \%)$ do not agree. $(56.6 \%)$ of the sample members agree that the company motivates workers financially and morally in order to implement the comprehensive quality system as well as its endeavor to solve workers' problems, while $(6.7 \%)$ of them do not agree. Among the most prominent variables that contributed to enriching the study variables are (X1, $\mathrm{X} 4, \mathrm{X} 5$ ), and this indicates that the appointment in the researched company is done according to these answers came with a mean of (3.36) and a standard deviation of (1.234). The sample trends came in agreement with all the variables of the standard of measurement, analysis and knowledge management, (Table 7) of the frequency distributions, percentages, the arithmetic mean and the standard deviation of the concentration criterion in human resources. 
Table (7): Frequency distributions, percentages and standard deviation of the concentration in human resources criterion.

\begin{tabular}{|c|c|c|c|c|c|c|c|c|c|c|c|c|c|c|}
\hline \multirow[b]{2}{*}{$\begin{array}{l}\text { concentration } \\
\text { in human } \\
\text { resources } \\
\text { criterion }\end{array}$} & \multicolumn{2}{|c|}{$\begin{array}{l}\text { Strongly } \\
\text { Agree }\end{array}$} & \multicolumn{2}{|c|}{ Agree } & \multicolumn{2}{|c|}{ Neutral } & \multicolumn{2}{|c|}{ Disagree } & \multicolumn{2}{|c|}{$\begin{array}{l}\text { Strongly } \\
\text { Disagree }\end{array}$} & \multirow[b]{2}{*}{ Mean } & \multirow[b]{2}{*}{ St.D } & \multirow{2}{*}{$\begin{array}{l}\text { Percentages } \\
\text { of } \\
\text { agreement } \\
\text { with } \\
\text { Question }\end{array}$} & \multirow[b]{2}{*}{$\begin{array}{l}\text { Sample } \\
\text { direction }\end{array}$} \\
\hline & Freq & $(\%)$ & Freq & $(\%)$ & Freq & $(\%)$ & Freq & $(\%)$ & Freq & $(\%)$ & & & & \\
\hline 1 & 2 & 6.65 & 21 & 70 & 3 & 10 & 2 & 6.65 & 2 & 6.7 & 3.63 & 0.964 & 72.7 & Agree \\
\hline 2 & 7 & 23.35 & 12 & 40 & 0 & 0 & 7 & 23.35 & 4 & 13.3 & 3.37 & 1.426 & 67.3 & Neutral \\
\hline 3 & 7 & 23.3 & 7 & 23.35 & 7 & 23.35 & 6 & 20 & 3 & 10 & 3.3 & 1.317 & 66 & Neutral \\
\hline 4 & 2 & 6.7 & 17 & 56.6 & 6 & 20 & 2 & 6.7 & 3 & 10 & 3.43 & 1.073 & 68.7 & Agree \\
\hline 5 & 2 & 6.7 & 17 & 56.6 & 4 & 13.3 & 2 & 6.7 & 5 & 16.7 & 3.3 & 1.236 & 66 & Neutral \\
\hline 6 & 6 & 20 & 5 & 16.7 & 10 & 33.3 & 7 & 23.3 & 2 & 6.7 & 3.2 & 1.215 & 64 & Neutral \\
\hline 7 & 7 & 23.3 & 8 & 26.7 & 6 & 20 & 4 & 13.3 & 5 & 16.7 & 3.27 & 1.413 & 65.3 & Neutral \\
\hline Average & 4.7 & & 12.4 & & 6.5 & & 4.3 & & 3.4 & & 3.36 & 1.234 & 67.1 & \\
\hline
\end{tabular}

6. Operations management criterion: We find that $(76.6 \%)$ of the sample members agree with the company's incorporation of modern technology and organizational knowledge into the design of work systems, and (16.7\%) of them agree strongly while $(6.7 \%)$ were neutral to that, and that $(56.6 \%)$ of the sample members agree with the company's possession of specific principles and procedures for designing new work systems, and $(6.7 \%)$ of them agree, while $(36.7 \%)$ of them were neutral to that and scientific foundations that serve the company's interest, and it also shows that the company motivates workers financially and morally to apply comprehensive quality standards in the field of services.

The most prominent variables that contributed to enriching the study variables are (X2, X3) This indicates that the researched company is working to integrate modern technology and organizational knowledge within the design of work systems, as it has specific work principles and procedures, and these answers came with an arithmetic mean (3.98) and a standard deviation of (0.671). The sample's trends came in agreement towards all the variables of the operations management standard, (Table 8).

Table (8): the frequency distributions, percentages, and standard deviation of the operations management criterion.

\begin{tabular}{|c|c|c|c|c|c|c|c|c|c|c|c|c|c|c|}
\hline \multirow{2}{*}{$\begin{array}{c}\text { operations } \\
\text { management } \\
\text { criterion }\end{array}$} & \multicolumn{2}{|c|}{$\begin{array}{c}\text { Strongly } \\
\text { Agree }\end{array}$} & \multicolumn{2}{|c|}{ Agree } & \multicolumn{2}{|c|}{ Neutral } & \multicolumn{2}{|c|}{ Disagree } & \multicolumn{2}{|c|}{$\begin{array}{c}\text { Strongly } \\
\text { Disagree }\end{array}$} & \multirow{2}{*}{$\begin{array}{c}\text { Percentages } \\
\text { of } \\
\text { agreement } \\
\text { with } \\
\text { question }\end{array}$} & $\begin{array}{c}\text { St.D } \\
\text { Sample } \\
\text { direction }\end{array}$ \\
\hline X1 & 8 & 26.7 & 13 & 43.3 & 9 & 30 & 0 & 0 & 0 & 0 & 3.97 & 0.765 & 79.3 & Agree \\
\hline X2 & 2 & 6.7 & 17 & 56.6 & 11 & 36.7 & 0 & 0 & 0 & 0 & 3.7 & 0.596 & 74 & Agree \\
\hline X3 & 5 & 16.7 & 23 & 76.6 & 2 & 6.7 & 0 & 0 & 0 & 0 & 4.1 & 0.481 & 82 & Agree \\
\hline X4 & 1 & 3.3 & 24 & 80 & 5 & 16.7 & 0 & 0 & 0 & 0 & 3.87 & 0.434 & 77.3 & Agree \\
\hline X5 & 10 & 33.3 & 12 & 40 & 7 & 23.3 & 1 & 3.4 & 0 & 0 & 4.03 & 0.85 & 80.7 & Agree \\
\hline X6 & 6 & 20 & 15 & 50 & 9 & 30 & 0 & 0 & 0 & 0 & 3.9 & 0.712 & 78 & Agree \\
\hline X7 & 7 & 23.3 & 14 & 46.7 & 9 & 30 & 0 & 0 & 0 & 0 & 3.93 & 0.74 & 78.7 & Agree \\
\hline X8 & 9 & 30 & 12 & 40 & 9 & 30 & 0 & 0 & 0 & 0 & 4 & 0.788 & 80 & Agree \\
\hline Average & 6 & & 16.2 & & 7.6 & & 0.1 & & 0 & & 3.98 & .671 & 78.8 & \\
\hline
\end{tabular}

7. The criterion for the results of the organization's management: We find that $(73.3 \%)$ of the sample members agree with the company's comparison of the results of its current performance levels of its strategies and plans with the performance levels of similar 
companies 'operations. (3.4\%) of them agree strongly, while $(23.3 \%)$ They were neutral to this, and that $(66.7 \%)$ of the sample members agree that the company was able to increase its sales and market share, and that $(13.3 \%)$ of them agree while $(20 \%)$ of them were neutral to that, and $(63.3 \%)$ of the sample members They agree with the company's ownership of the results of the current levels of leadership and employee development, and (10\%) of them agree, while $(26.7 \%)$ of them were neutral. Among the most prominent variables that contributed to enriching the study variables are (X1, X5, X6), and this indicates that the researched company compares the results of its current performance levels of its strategies and plans with the performance levels of competing companies and that the company was able to increase its sales and market share, as it possesses the results of the current levels of development. Leadership and employees, and these answers came with a mean (3.9) and a standard deviation of (0.72). The sample trends came in agreement with regard to most of the variables of the enterprise management results criterion, (Table 9).

Table (9): The frequency distributions, percentages, and standard deviation of the enterprise management results criterion.

\begin{tabular}{|c|c|c|c|c|c|c|c|c|c|c|c|c|c|c|}
\hline \multirow{2}{*}{$\begin{array}{l}\text { enterprise } \\
\text { management } \\
\text { results } \\
\text { criterion }\end{array}$} & \multicolumn{2}{|c|}{$\begin{array}{l}\text { Strongly } \\
\text { Agree }\end{array}$} & \multicolumn{2}{|c|}{ Agree } & \multicolumn{2}{|c|}{ Neutral } & \multicolumn{2}{|c|}{ Disagree } & \multicolumn{2}{|c|}{$\begin{array}{l}\text { Strongly } \\
\text { Disagree }\end{array}$} & \multirow{2}{*}{ Mean } & \multirow{2}{*}{ St.D } & \multirow{2}{*}{$\begin{array}{l}\text { Percentages of } \\
\text { agreement } \\
\text { with question }\end{array}$} & \multirow{2}{*}{$\begin{array}{l}\text { Sample } \\
\text { direction }\end{array}$} \\
\hline & Freq & $(\%)$ & Freq & $(\%)$ & Freq & $(\%)$ & Freq & $(\%)$ & Freq & $(\%)$ & & & & \\
\hline $\mathrm{X} 1$ & 1 & 3.4 & 22 & 73.3 & 7 & 23.3 & 0 & 0 & 0 & 0 & 3.8 & 0.48 & 76 & Agree \\
\hline $\mathrm{X} 2$ & 9 & 30 & 15 & 50 & 4 & 13.3 & 2 & 6.7 & 0 & 0 & 4.03 & 0.85 & 80.7 & Agree \\
\hline $\mathrm{X} 3$ & 4 & 13.3 & 10 & 33.4 & 9 & 30 & 4 & 13.3 & 3 & 10 & 3.27 & 1.17 & 65.3 & Neutral \\
\hline $\mathrm{X} 4$ & 11 & 36.7 & 12 & 40 & 7 & 23.3 & 0 & 0 & 0 & 0 & 4.13 & 0.77 & 82.7 & Agree \\
\hline $\mathrm{X} 5$ & 4 & 13.3 & 20 & 66.7 & 6 & 20 & 0 & 0 & 0 & 0 & 3.93 & 0.58 & 78.7 & Agree \\
\hline X6 & 3 & 10 & 19 & 63.3 & 8 & 26.7 & 0 & 0 & 0 & 0 & 3.83 & 0.59 & 76.7 & Agree \\
\hline $\mathrm{X} 7$ & 6 & 20 & 16 & 53.3 & 8 & 26.7 & 0 & 0 & 0 & 0 & 3.93 & 0.69 & 78.7 & Agree \\
\hline $\mathrm{X} 8$ & 7 & 23.3 & 18 & 60 & 5 & 16.7 & 0 & 0 & 0 & 0 & 4.07 & 0.64 & 81.3 & Agree \\
\hline Average & 0.7 & & 17.0 & & $7 . \wedge$ & & $\cdot \wedge$ & &.$\varepsilon$ & & r.9 & $\cdot V Y$ & $V Y .0$ & \\
\hline
\end{tabular}

\section{Second: Test the research hypotheses}

For the purpose of assessing the actual reality of the extent to which the company applies the research sample to Malcolm criteria in the degree, the actual verifier must be identified and the gap between it and the degree of standards determined, so the percentages of each criterion and the actual investigator for each standard and the rate of the gap between them will be calculated.

We note from the above table that the percentage of the actual achievement of the leadership criterion is $(80.60 \%)$ and the gap rate is (19.4\%). With regard to strategic planning, a percentage of $(77.6 \%)$ was actually achieved and a gap rate of $(22.4 \%)$, and the criterion of focusing on the customer was scored (82.6\%). Actually achieved and prepared a gap of $(17.4 \%)$, while the standard of measurement, analysis and knowledge management scored (76.7\%) actually achieved and prepared a gap of (23.3\%). As for the criterion of concentration in human resources, the lowest percentage actually achieved was (67.1). The gap rate was $(32.9 \%)$, which is the largest rate, and the standard of operations management $(78.8 \%)$ was actually, (Table 10). 
Table (10): Actual verified percentages and gap rates.

\begin{tabular}{|c|c|c|c|c|c|}
\hline Criteria & $\begin{array}{c}\text { Criterion } \\
\text { score in the } \\
\text { award }\end{array}$ & $\begin{array}{c}\text { Actual } \\
\text { Verifier }\end{array}$ & $\begin{array}{c}\text { Percentage of the } \\
\text { actual verifier of his } \\
\text { score in the Criterion } \\
(\%)\end{array}$ & Gap rate & $\begin{array}{c}\text { Percentage of the gap } \\
\text { average of his score in } \\
\text { the Criterion } \\
\text { (\%) }\end{array}$ \\
\hline Leadership & 120 & 96.72 & 80.60 & 23.28 & 19.4 \\
\hline Strategic planning & 85 & 65.96 & 77.6 & 19.04 & 22.4 \\
\hline Focus on the customer & 85 & 70.21 & 82.6 & 14.79 & 17.4 \\
\hline $\begin{array}{c}\text { Measurement, } \\
\text { analysis and } \\
\text { knowledge } \\
\text { management }\end{array}$ & 90 & 69.03 & 76.7 & 20.97 & 23.3 \\
\hline $\begin{array}{c}\text { Emphasis in human } \\
\text { resources }\end{array}$ & 85 & 57.035 & 67.1 & 27.965 & 32.9 \\
\hline $\begin{array}{c}\text { Operations } \\
\text { management }\end{array}$ & 85 & 66.98 & 78.8 & 18.02 & 21.2 \\
\hline $\begin{array}{c}\text { Enterprise } \\
\text { management results }\end{array}$ & 450 & 348.75 & 77.5 & 101.25 & 22.5 \\
\hline Total & 1000 & 774.685 & & & \\
\hline
\end{tabular}

Achieved, and a gap rate $(21.2 \%)$. As for the corporate management results criterion, it was recorded $(77.5 \%)$ and a gap rate $(22.5 \%)$. This indicates that the degree of application of Malcolm Baldrige criteria for total quality in the company, the research sample is good.

\section{CONCLUSIONS}

1. The company obtained the research sample on $(774,685)$ points out of $(1000)$ the total points of Malcolm Baldrige criteria for total quality and this indicates the achievement of a good level of standards in the company from the degree of the criterion in the award.

2. The trends of the sample came in agreement and strongly agreement with most of the variables of the standard of leadership and strategic planning and focusing on the customer. However, there is weakness in the company's management in communicating with the workers, sharing their opinions and dealing with them fairly, and in dealing with disasters and crises that society is exposed to in a positive and effective manner, and the presence of deficiencies. In the mechanisms adopted by the company to win and maintain its customers, and in comparing their level of satisfaction with competitors.

3. The sample trends came in agreement with most of the variables of the measurement standard, analysis and knowledge management, the standard of operations management and the results of the organization's management. However, there is a weakness in the company's preparation for the self-evaluation report and the use of the review results in order to improve the company's performance and ensure innovation.

4. The sample's trends came towards neutrality towards the criterion of concentration in human resources in terms of developing the spirit of teamwork among employees and developing their skills through training and cultural programs and the presence of weakness in the company's adoption of specific foundations for managing professional advancement and job positions in the company.

5. There is a weakness in the company's publishing of the annual work plan among employees to achieve its goals and also does not amend its strategic plans based on the results of performance measures.

6. The lack of meetings of managers with employees to explain the company's strategy and its impact on customers. 
7. There is a weakness in the company's benefit from the information received by it through market research in developing the quality of after-sales services provided to customers.

\section{RECOMMENDATION}

1. The necessity of adopting Malcolm Baldrige seven criteria for comprehensive quality in the field of after-sales services and working to apply them in private sector companies because of these services have a great impact on satisfying and maintaining consumers, as well as for the company to obtain the largest market share in the market.

2. The necessity for companies to conduct training courses for workers to get acquainted with the latest developments in this field.

3. Employing workers with good experience in providing after-sales services in order to provide the highest level of quality in order to satisfy the needs and expectations of customers.

4. Working on spreading the company's strategy in achieving its goals among all employees of the company and trying to involve them in it and presenting their suggestions about the quality of after-sales services.

5. The need for the company's senior management to work on continuous development and improvement in the quality of its services provided to customers in order to satisfy them and achieve profits by making use of the information resulting from market research.

6. Involving workers in the decision-making process regarding the quality of after-sales services.

\section{REFERENCES}

1. Abdul Razzaq, A. N. (2011). The use of information technology to ensure the quality of health service-a case study in a sample of hospitals in the city of Baghdad. Journal of Administration and Economics, 34(90), 281-298.

2. Al-Dewa, G. A. (2001). International Marketing. Dar Al-Hamed, Amman, 30.

3. Al-Fkaiki, A. F. A. \& Al-Shohani, A. D. H. (2016). Total quality management in the qur'an. Iraqi Journal of Market Research and Consumer Protection, 8(1), 340-366.

4. Al-Hamdany, R. A. R. \& Abd, R. M. (2018). The role of services quality dimensions in supporting customer value-a pilot study of the opinions of some clients in the north bank for finance and investment in Nineveh governorate. Rafidain Development. 37(119), 2643.

5. Aqaili, O. W. (2001). The Integrated Methodology for Total Quality Management-A Viewpoint. $1^{\text {st }}$ ed., Wael Publishing House, Amman-Jordan, 188.

6. Al- Saffar, N. A. \& Obeidat, A. M. (2020). The effect of total quality management practices on employee performance: the moderating role of knowledge sharing, Management Science Letters, 10, 77-90.

7. Baldrige National Quality Program. (2014). Criteria for Performance Excellence. National Institute of Standards and Technology, Department of Commerce, United States. 3.

8. Chatheer, S. H., Muhammad, S. K. \& Abdul Razzaq, A. N. (2012). The effect of health marketing information system on increasing the efficiency of the health service provider's performance, Baghdad College of Economic Sciences Journal. 32, 35-60.

9. Hammoud, K. K. (2007). Quality and Customer Service Management. $2^{\text {st }}$ ed., Maisarah House for Publishing and Distribution. Jordan, 215.

10. Hussein, H. F. \& Abboud, S. M. (2013). The effect of service quality dimensions on the degree of consumer preference (Commercial Markets-Malls-Model). Iraqi Journal of Market Research and Consumer Protection, 5(1), 94-114. 
11. Hussein, W. A. \& Laftah. B. S. (2019). The elements of economic intelligence of the organization and its role in achieving economic growth. Journal of Accounting and Financial Studies, 14(47), 1-14.

12. Jahida, M. \& Abdel, W. R. (2016). The impact of after-sales services on consumer loyalty to the brand-condor. Maaref Revue academlque, 11, 174-193.

13. Kouachi, M. (2013). Measuring the distinguished performance of institutions through the models of the international quality awards. Journal of the College of Economic and Business Sciences and Facilitation Sciences, 1(14), 317-333.

14. Krajewski, L. J., Ritzman, L. O. \& Malhotra, M. K. (2010). Operations Management, $9^{\text {th }}$ ed., Pearson Education, Inc., New Jersey, 221.

15. Rashid, F. \& Gamal, A. (2020). After sales services and their impact on customer satisfaction. Journal of Organization and Work, 8(4), 43-62. 